\title{
Trace Metals in Surface Soil Contaminated by Release of Phosphate Industry in the Surroundings of Sfax-Tunisia
}

\author{
Ahmed Wali ${ }^{1}$, Gilles Colinet ${ }^{2}$, Moncef Khadhraoui ${ }^{1}$, Mohamed Ksibi ${ }^{1 *}$ \\ ${ }^{1}$ Laboratory of Water, Energy and Environment, University of Sfax, National School of Engineers of Sfax \\ (ENIS), Route de Soukra Km 3.5 Po. Box 1173, 3038 Sfax, Tunisia \\ ${ }^{2}$ Unit of Soil and Water Systems, University of Liege, Gembloux Agro-Bio Tech, Belgium \\ *Corresponding Author. Email: mohamed.ksibi@tunet.tn; Tel: +216674354 Fax: +21674674 363

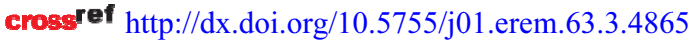

(Received in July, 2013; accepted in September, 2013)

\begin{abstract}
There is a worldwide growing concern about soil pollution caused by phosphate industry creating thus large amounts of phosphogypsum slurry. This slurry is piped from the processing facilities up into acidic wastewater ponds that sit atop the mountainous waste piles known as gypsum stacks. This issue is of special interest because of toxic metals threats to groundwater tables as well as to the surrounding environment.

The aim of the present work is to assess the level of trace elements content in soil around stocked solid waste "a phosphogypsum" derived from a former phosphate fertilizers factory and to investigate their factors of variation. Twenty soil samples were collected at the depths of $20 \mathrm{~cm}$ and analyzed for their physicochemical properties, the content of their major elements (Ca, Mg, $\mathrm{K}, \mathrm{Na}, \mathrm{Al}, \mathrm{Fe}, \mathrm{Mn})$, and some trace elements such as $\mathrm{Zn}, \mathrm{Pb}, \mathrm{Cr}, \mathrm{Cu}, \mathrm{Co}$ and $\mathrm{Ni}$. Data were processed with multivariate statistical analysis in order to investigate relationships among the trace elements and the factors controlling their distribution in the phosphogypsum surrounding environment. Enrichment factors (EF) were calculated to assess either natural and/or anthropogenic origins. The results indicate moderate levels of contamination and big differences in variability among elements. The maximal and mean concentrations found in soil, except the soil sample S5.1, were 95.2 and $36.5 \mathrm{mg} \mathrm{Kg}^{-1}$ for $\mathrm{Zn}, 75.2$ and $30.23 \mathrm{mg} \mathrm{Kg}^{-1}$ for $\mathrm{Pb}, 28.4$ and $17.5 \mathrm{mg} \mathrm{Kg}^{-1}$ for $\mathrm{Cr}, 61.9$ and $15.6 \mathrm{mg} \mathrm{Kg}^{-1}$ for $\mathrm{Cu}, 5.28$ and $2.7 \mathrm{mg} \mathrm{Kg}^{-1}$ for $\mathrm{Co}$, and 13.2 and $6.4 \mathrm{mg} \mathrm{Kg}^{-1}$ for Ni. Most of the elements were positively correlated with $\mathrm{pH}$ and cation-exchange capacity, and no correlation with total organic carbon and electrical conductivity except for $\mathrm{Cu}, \mathrm{Zn}$ and $\mathrm{Pb}$ was found. The EF values of the most trace metals were higher than 1.5 indicating that the phosphate fertilizer industry had an anthropogenic effect causing a negative impact on the environment. The relatively increased amount of toxic metals in the examined soils requires the area to be controlled since a variety of agricultural activities are conducted nearby moreover the surroundings are programmed to be residential zones.
\end{abstract}

Keywords: trace metal; phosphogypsum; Pearson and Spearman correlation; principal component analysis; soil pollution.

\section{Introduction}

Metal contamination of soil potentially jeopardizes the quality and the function of all biosphere components. Sources of contamination include, traffic emissions, power transmission, intensive agriculture (Sun et al. 2007; Maas et al. 2010), mining and refining of metals, sludge dumping and industrialization (Varun et al. 2012). In Tunisia, phosphoric acid production represents an important industrial activity. The production of phosphoric acid from natural phosphate rock mainly mined in Gafsa (South west of Tunisia) by means of wet processes gives rise to an industrial by-product named phosphogypsum (PG) (Chakchouk and Trabelsi 1989). The problems associated with this solid waste 
are numerous due to its strong acidity, and presence of numerous potential contaminants. Chemical analysis of some phosphogypsum samples revealed the presence of significant quantities of various toxic compounds such as fluor, metals (lead, zinc, mercury, copper, and cadmium), salts and radioactive elements (Rouis and Bensalah 1990). Phosphogypsum $\mathrm{pH}$ is always very low (around 2), because it is stored without neutralization. Rain and storage water can percolate easily through the phosphogypsum pile and carry the contaminants to the surrounding soils and to groundwater. Relatively high hydraulic conductivity of stored phosphogypsum $\left(10^{-5}\right.$ to $\left.10^{-6} \mathrm{~cm} \mathrm{sec}^{-1}\right)$ and the absence of a watertight barrier between the pile and the natural soil is a powerful factor of a potential pollution. Trace metals are considered crucial contaminants because they cannot be degraded and tend to accumulate in soil, water, animal, plant, and humans after entering the food chain. Many researchers have reported significant toxicity of nickel, chromium, cadmium, cobalt, lead, and zinc and their potential damages to the nervous system, to the internal organs, and as carcinogenic factors especially to young children, (Lee et al. 2007; Maas et al. 2010). Many studies have also examined the relationships among elements (major and trace), and between elemental concentrations, and other soil properties (clay content, cation exchange capacity, $\mathrm{pH}$, soil texture, carbonates) in contaminated or noncontaminated soils (Vega et al. 2004; Covelo 2007). Taking this in consideration, disposing phosphogypsum directly into the environment without any pre-treatment, or its storage as a pile exposed to weathering processes, may lead to chemical and radioactive contamination with trace metals (Rutherford et al. 1994). Leaching of phosphogypsum with water shows that $\mathrm{Cu}$ and $\mathrm{Cd}$ can be easily transferred into the ground water and to the surrounding environment (Al-Masri et al. 2004). In her study Carvalho (1995) shows that increasing sand proportion in soil is found to have a diluting effect on the concentration of $\mathrm{Pb}$, since this metal is considered as a non-reactive agent in a sandy soil. Similar results are found by Al-Masri et al. (2004), who had confirmed that trace elements are always concentrated in a fine particle fraction. Variation of parameters such as temperature, pressure, and concentrations of salts affect the distribution of elements. Al-Masri et al. (2004) have sustained this conclusion in their survey of the distribution of trace elements in Syrian phosphogypsum.

In this study, the distribution of major elements ( $\mathrm{Ca}, \mathrm{Mg}, \mathrm{K}, \mathrm{Na}, \mathrm{Al}, \mathrm{Fe}, \mathrm{Mn}$ ) and trace elements ( $\mathrm{Zn}$, $\mathrm{Pb}, \mathrm{Cr}, \mathrm{Cu}, \mathrm{Co}$ and $\mathrm{Ni}$ ) is investigated around the Sfax region (central eastern coast of Tunisia) where a phosphate fertilizer industry is located at $34^{\circ} 42^{\prime} 10^{\prime \prime}$ $\mathrm{N}, 10^{\circ} 43^{\prime} 26^{\prime \prime} \mathrm{E}$ and which is storing its solid waste, without any pre-treatment, directly into exposed landfills in the surrounding environment. Contaminants are studied on the particle fractions less than $200 \mu \mathrm{m}$. The main goal is to evaluate the impact of such waste on soil and to identify the most influencing factors of distribution of contaminants. Samples of topsoil $(0-20 \mathrm{~cm}$ depth) are extracted using the solution of $\mathrm{HF}-\mathrm{HClO} 4-\mathrm{HCl}$. Data are evaluated with statistical multivariate analysis techniques, i.e., Spearman and Pearson Correlation and Principal Component Analysis (PCA). This stastical analysis provides relevant information on the sources of contamination and relationships among trace metals and other properties as reported by Lucho-Constantinoa et al. (2005) and Cai et al. (2012). The lithogenic or anthropogenic origin of trace metals and the importance of contamination are evaluated by using enrichment factors (Zoller et al. 1974; Micó et al. 2006).

\section{Material and methods}

\subsection{Study area and soil sampling}

Sfax is a city with dry climate (average precipitation: $210 \mathrm{~mm}$ ) influenced by the hot southerly winds known as Sirocco. The study has been conducted around a Sfaxian chemical fertilizer enterprise which produces a wide range of phosphates. Residues of the production of this enterprise are being thrown into two enormous dumping grounds of phosphogypsum. The first one is 12 meters high and covers an area of 40 ha, however the other is 30 meters high and covers an area of 60 ha. These two dumping grounds are situated on the coastal strip of the urban area and unload into the sea. Solid particles are carried by wind, as well as acids and washed particles. At several altitudes around the industrial complex, many residential units are distributed intermittently. Small industries of metallurgy and plastic are located in the north and the north-east of the enterprise whereas a waste water treatment plant is situated in the south-west of this fertilizer industry. The region is limited by the sea and El Maou Oued in the south-east and the road in the north (Figure 1). Dominant wind direction is mostly blowing from the south or the south-west and occasionally from the north, especially during the fall season, and the water flow is in the direction eastwest, direction of Oued.

The soil in the studied area is calcareous with scant development of sandy-loam texture (Choura 2007). A groundwater assessment of this area has revealed the existence of a highly polluted zone in the vicinity of the pile, as reported by Kobbi-Rebai et al. (2012). Based on these previous results, samples are taken from the north, south, east, and west directions of a dumping phosphogypsum pile because on-site marshes and adjacent estuaries pose a potential risk to ecological receptors. The sampling design adopted in the studied area consists of five marked line transects across the surface of the dumping grounds of phosphogypsum according to the circulation of water masses. To obtain the information on metals diffusion in all directions, 20 soil samples are collected at regular intervals $(100 \mathrm{~m})$ along the transect lines with an Edelman-type auger into the soil 
to a depth of approximately $20 \mathrm{~cm}$. The reference soil samples are collected from a non urban region (Elhajeb site) located at around $17 \mathrm{~km}$ from the south- west of the study area. The sampling was performed in December, 2011.

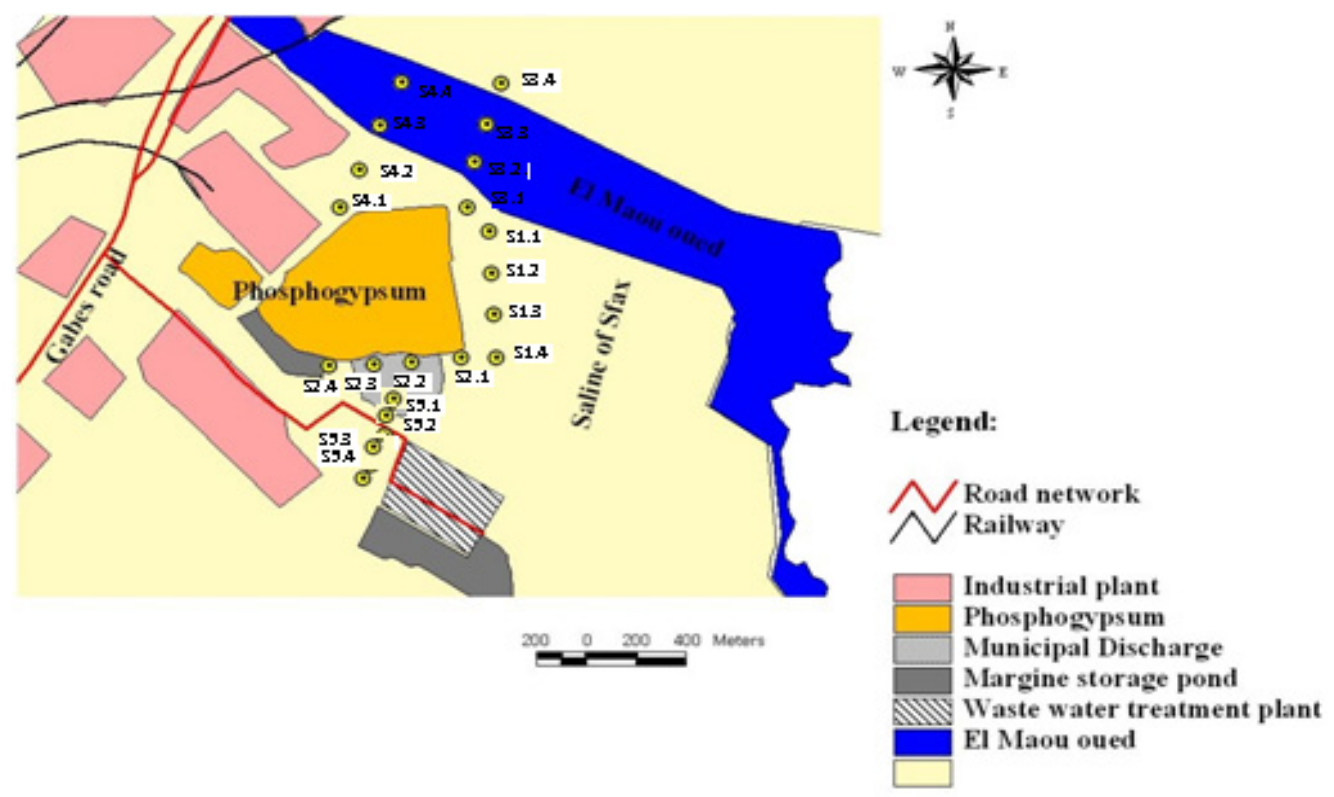

Fig.1. Map of sampling in the vicinity of the pile (Sfax City)

\subsection{Analytical methods}

Soil samples were air-dried at the room temperature $\left(20-25^{\circ} \mathrm{C}\right)$, stones or other debris were removed, then sieved through a $200 \mu \mathrm{m}$ mesh screen and stored in polyethylene bottles until further use. Electrical conductivity (EC) and $\mathrm{pH}$ were determined in a 1:5 material/water ratio according to the method described by Rayment and Higginson (2002). Total organic carbon (TOC) was determined by the modified Springer-Klee method (Ciavatta et al. 1989). Cation exchange capacity (CEC) was determined according to the ISO 23470 (2007) and calcium carbonate was determined by the method described by the U.S Salinity Laboratory (1954). Total metal concentrations were determined using an atomic absorption spectrophotometer (Spectro A.A 220Varian, Australia) after digestion with a HF-HClO4$\mathrm{HCl}$ solution according to the technical protocol developed by the AFNOR Certification: NF X 31-147 (1996). Certified soils references (MRI-E 2005) were also used to check the accuracy of the results. The recovery rates for the elements analyzed were $99 \%$ for $\mathrm{Co}, 98 \%$ for $\mathrm{Ni}, 99 \%$ for $\mathrm{Cr}, 96 \%$ for $\mathrm{Pb}, 97 \%$ for $\mathrm{Zn}, 96 \%$ for $\mathrm{Cu}, 104 \%$ for $\mathrm{Mn}, 98 \%$ for $\mathrm{Al}, 99$ $\%$ for $\mathrm{Fe}, 99 \%$ for $\mathrm{Ca}, 105 \%$ for $\mathrm{Na}, 104 \%$ for $\mathrm{K}$ and $106 \%$ for $\mathrm{Mg}$. Phosphogypsum and reference soil were also digested with the $\mathrm{HF}-\mathrm{HClO} 4-\mathrm{HCl}$ solution to compare with all the soil samples collected from the study sites.

\subsection{Enrichment factors}

To determine a relative degree of metal contamination, comparisons were made with reference concentrations in a soil sample using Fe as a reference element, following the assumption that its content in the soil was not disturbed by anthropogenic activity. The enrichment factors (EF) were calculated according to the equation generalized by Zoller et al. (1974). Then Fe was chosen to calculate EF. According to Ergin et al. (1991) EFs are defined by the following equation (1). Gargouri et al. (2010) and Ghannem et al. (2010) used that formula for the assessment of heavy metal concentrations in the surface marine sediments of Sfax Coast (Tunisia).

$\mathrm{EF}=\frac{\left(\frac{C_{m}}{C_{F e}}\right) \text { sample }}{\left(\frac{C_{m}}{C_{F e}}\right) \text { background }}$

where:

$\left(\frac{C_{m}}{C_{F e}}\right)_{\text {sample }}$-the ratio of the concentration of trace metals $(\mathrm{Cm})$ to that of $\mathrm{Fe}\left(\mathrm{C}_{\mathrm{Fe}}\right)$ in the soil sample;

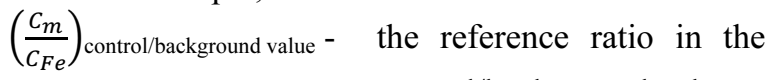
control/background value.

\subsection{Statistical analysis}

Descriptive statistical parameters were calculated with the commercial statistics software package SPSS version 18.0 for Windows. Principal Component Analysis (PCA), Spearman and Pearson correlation were used to analyze the multivariate relationships among soil properties, major and trace element concentrations in environmental studies and their possible sources (Micó et al. 2006; Cai et al. 2012). Pearson coefficient of correlation was statistically analyzed at a significance level of $\mathrm{P}<0.05$ and $\mathrm{P}<0.01$. 


\section{Results and discussion}

\subsection{Environmental impact of phosphogypsum on the studied area}

The storage of phosphogypsum (PG) without any prior treatment requires large land areas and can cause serious environmental contamination to soil, water, and the surrounding environment. Negative atmospheric impacts can be caused by both erosion of PG piles and release of highly polluting substances, due to the presence of hazardous vapors containing trace metals. Trace metals including, $\mathrm{Zn}, \mathrm{Cu}, \mathrm{Pb}, \mathrm{Cr}$,
$\mathrm{Ni}$, and Co have been measured from the dumping grounds of $\mathrm{PG}$ and are summarized in Table 1. Results clearly show that the trace metal content is similar to that found by other authors (Azabou et al. 2005; Tayibi et al. 2009; Szynkowska et al. 2009; Perez-Lopez et al. 2010). Regarding these results, it is obvious that the concentrations of trace metals in the PG surrounding area are much higher than in the reference soil except for $\mathrm{Co}$ and $\mathrm{Ni}$. Thus, the amount of pollution that can often enter the surrounding environment can have a negative impact on the quality of human life and the environment.

Table 1. Content of some trace elements $\left(\mathrm{mg} \mathrm{Kg}^{-1}\right)$ in phosphorgypsum (PG), reference and contaminated soils at Sfax region

\begin{tabular}{|l|c|r|c|c|c|c|c|c||}
\hline \hline Element & PG $^{\mathbf{a}}$ & $\mathbf{P G}^{\mathbf{b}}$ & $\mathbf{P G}^{\mathbf{c}}$ & $\mathbf{P G}^{\mathbf{d}}$ & $\mathbf{P G}^{\mathbf{e}}$ & Ref-Soil $^{\mathbf{a}}$ & Mean-Soil (N=19) $^{\mathbf{a}}$ & $\mathbf{S}_{\mathbf{5 - 1}}$ \\
\hline $\mathrm{Zn}\left(\mathrm{mg} \mathrm{Kg}^{-1}\right)$ & 190.0 & $50-100$ & 315.0 & - & 5.63 & 11.2 & 36.5 & 282.1 \\
\hline $\mathrm{Pb}\left(\mathrm{mg} \mathrm{Kg}^{-1}\right)$ & 23.0 & $<5$ & 5.0 & 22.2 & 4.46 & 4.4 & 30.2 & 30.5 \\
\hline $\mathrm{Ni}\left(\mathrm{mg} \mathrm{Kg}^{-1}\right)$ & $<\mathrm{LD}$ & $3-5$ & 15.0 & 7.95 & 1.46 & 3.4 & 6.4 & 23.1 \\
\hline $\mathrm{Cu}\left(\mathrm{mg} \mathrm{Kg}^{-1}\right)$ & 4.4 & $5-18$ & $6-12$ & 14.4 & 4.92 & 7.7 & 15.6 & 49.4 \\
\hline $\mathrm{Cr}\left(\mathrm{mg} \mathrm{Kg}^{-1}\right)$ & 17.6 & $10-30$ & 20.0 & 14.7 & 10.9 & 7.1 & 7.5 & 82.4 \\
$\mathrm{Co}\left(\mathrm{mg} \mathrm{Kg}^{-1}\right)$ & 5.5 & - & 8.0 & - & - & 1.1 & 2.8 & 5.3 \\
\hline
\end{tabular}

a: Our study; b: Azabou et al. (2005); c: Tayibi et al. (2009); d: Szynkowska et al. (2009); e:Perez-Lopez et al. (2010)

The $S_{5-1}$ sample has been removed from the 19 other ones as it appears as an outlier for most elements.

\subsection{Characteristics of soil and descriptive statistics}

Table 2 and Table 3 summarize the physicalchemical properties and trace metal content of soil samples. Sample S5-1, the closest to the pile and in the stream of run-off water, appeared to be highly contaminated with most elements contained in PG. It has been considered as an outlier value and discarded from the other nineteen samples for further statistical analysis.

Table 2. Descriptive statistics about physical-chemical properties of 19 soil samples (in the depth 0-20 cm) at the Sfax region

\begin{tabular}{||l|l|l|l|l|l|l|l|l|l||}
\hline & Mini & Max & Median & Mean & S.D & CV & Skewness & Kurtosis & S $_{\text {5-1 }}$ \\
\hline $\mathrm{pH}$ & 7.20 & 9.02 & 8.27 & 8.17 & 0.52 & 0.06 & -0.45 & -0.70 & 6.63 \\
\hline TOC $(\%)$ & 0.15 & 1.75 & 0.62 & 0.66 & 0.33 & 0.50 & 2.04 & 6.30 & 2.05 \\
$\mathrm{CaCO}_{3}(\%)$ & 8.75 & 21.12 & 12.62 & 13.43 & 3.46 & 0.21 & 0.74 & -0.33 & 10.25 \\
\hline $\mathrm{CEC}\left(\mathrm{cmol}_{\mathrm{c} \mathrm{kg}} \mathrm{kg}^{-1}\right)$ & 4.61 & 11.94 & 6.70 & 7.22 & 2.07 & 0.29 & 0.99 & 0.36 & 16.49 \\
$\mathrm{EC}\left(\mathrm{mS} \mathrm{cm}^{-1}\right)$ & 0.63 & 24.00 & 5.80 & 8.68 & 6.79 & 0.78 & 1.00 & 0.20 & 13.60 \\
\hline
\end{tabular}

The $S_{5-1}$ sample has been removed from the 19 others as it appears as an outlier for most elements

Kolmogorov-Smirnov test $(\beta=0.05)$ has been performed to test normal distribution of soil properties. It appears that only the content of TOC, $\mathrm{Na}, \mathrm{Ni}$ and $\mathrm{Cu}$ should not be considered as presenting normal distribution within the study area. A logarithmic transformation of the data allows researchers to reach normality, excepted for the $\mathrm{Ni}$ content, which can be explained by the occurrence of numerous values below the limit of quantification. Data analyses of the Pearson correlation coefficient and principal component have been performed using log-transformed data. Spearman coefficients are adapted to the analysis of correlation between untransformed and skew distributions.

Results of the analyzed soil properties in the study area summarized in Table 2 show that the $\mathrm{pH}$ values vary from 7.20 to 9.02 with a mean value of 8.17, which suggests neutral to sub-alkaline conditions for all the soil samples. Soil alkalinity is associated with the presence of calcium carbonate $\left(\mathrm{CaCO}_{3}\right)$ as shown in Table 2 . The TOC values range from 0.15 to $1.75 \%$ with a median value of 0.62 and a mean value of $0.66 \%$. CEC of the soil is rather low,

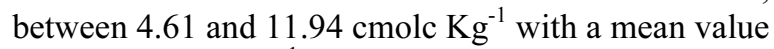
of 7.22 cmolc $\mathrm{Kg}^{-1}$. CEC is largely determined by organic matter and clay content and in alkaline conditions by $\mathrm{Fe}$ and $\mathrm{Al}$ oxides. As $\mathrm{pH}$ increases, the negative charge on such surfaces is increased, and hence adsorption of cations occurs. High concentration of Ca may also lead to the reduction of P or Fe solubility (Deka and Sarma 2012).

Descriptive statistics of trace metal concentrations $(\mathrm{mg} \mathrm{Kg})^{-1}$ are given in Table 3 . Skewness and kurtosis values of trace metals, except $\mathrm{Ni}$ and $\mathrm{Cr}$, are higher than the unit which is very frequent (Cai et al. 2012). Based on the coefficients of variation $(\mathrm{CV})$, the studied trace and major elements can be classified into three groups: (i) $\mathrm{Al}, \mathrm{Mn}$, and $\mathrm{K}$ with $\mathrm{CV}$ values lower than 0.25 ; (ii) $\mathrm{Fe}, \mathrm{Zn}, \mathrm{Pb}, \mathrm{Ni}$, $\mathrm{Co}, \mathrm{Cr}, \mathrm{Mg}$ and $\mathrm{Ca}$ with $\mathrm{CV}$ values in the range 0.250.75 , and (iii) $\mathrm{Cu}$ and $\mathrm{Na}$ with $\mathrm{CV}$ values higher than 0.75 . 
Table 3. Descriptive statistics about total concentrations in trace and major elements of 19 soil samples (at a depth of 0-20 cm) at Sfax region

\begin{tabular}{|l|c|r|r|r|r|r|r|r|r||}
\hline Element & Mini & Max & Median & Mean & S.D & CV & Skewness & Kurtosis & S $_{5-1}$ \\
\hline $\mathrm{Al}(\%)$ & 1.08 & 2.47 & 1.51 & 1.57 & 0.34 & 0.22 & 1.03 & 1.33 & 2.43 \\
\hline $\mathrm{Fe}(\%)$ & 0.50 & 1.37 & 0.83 & 0.81 & 0.21 & 0.26 & 0.96 & 1.49 & 3.59 \\
\hline $\mathrm{Mn}\left(\mathrm{mg} \mathrm{Kg}^{-1}\right)$ & 89.7 & 190 & 127.5 & 132.1 & 23.0 & 0.17 & 0.63 & 1.39 & 239 \\
\hline $\mathrm{Zn}\left(\mathrm{mg} \mathrm{Kg}^{-1}\right)$ & 13.2 & 95.2 & 34.4 & 36.5 & 20.4 & 0.56 & 1.32 & 2.50 & 282 \\
\hline $\mathrm{Pb}\left(\mathrm{mg} \mathrm{Kg}^{-1}\right)$ & 12.3 & 75.2 & 24.7 & 30.2 & 15.6 & 0.51 & 1.55 & 2.72 & 30.5 \\
\hline $\mathrm{Ni}\left(\mathrm{mg} \mathrm{Kg}^{-1}\right)$ & - & 13.2 & 6.8 & 6.4 & 3.9 & 0.62 & -0.43 & -0.19 & 23.1 \\
\hline $\mathrm{Cu}\left(\mathrm{mg} \mathrm{Kg}^{-1}\right)$ & 4.4 & 61.9 & 10.1 & 15.6 & 14.8 & 0.95 & 2.05 & 4.49 & 49.4 \\
\hline $\mathrm{Cr}\left(\mathrm{mg} \mathrm{Kg}^{-1}\right)$ & 11.8 & 28.4 & 16.7 & 17.5 & 4.9 & 0.28 & 1.04 & 0.19 & 82.4 \\
\hline $\mathrm{Co}\left(\mathrm{mg} \mathrm{Kg}^{-1}\right)$ & 1.38 & 5.28 & 2.55 & 2.7 & 0.84 & 0.31 & 1.59 & 4.32 & 5.27 \\
\hline $\mathrm{Ca}\left(\mathrm{mg} \mathrm{Kg}^{-1}\right)$ & 1211 & 6378 & 3825 & 4075 & 1564 & 0.38 & -0.03 & -097 & 6670 \\
\hline $\mathrm{Mg}\left(\mathrm{mg} \mathrm{Kg}^{-1}\right)$ & 206 & 1367 & 675 & 653 & 309 & 0.47 & 0.48 & -0.06 & 2120 \\
\hline $\mathrm{K}\left(\mathrm{mg} \mathrm{Kg}^{-1}\right)$ & 688 & 1207 & 961 & 954 & 152 & 0.16 & -0.06 & -058 & 605 \\
\hline $\mathrm{Na}\left(\mathrm{mg} \mathrm{Kg}^{-1}\right)$ & 153 & 3138 & 625 & 1016 & 863 & 0.84 & 1.21 & 0.72 & 3205 \\
\hline
\end{tabular}

The $S_{5-1}$ sample has been removed from the 19 others as it appears as an outlier for most elements.

Iron, aluminum and manganese are abundant in soil. An increase in their concentrations can't be easily distinguished from the already high background levels. In conditions of our study these elements are poorly mobile. Indeed, at high $\mathrm{pH}$ values, manganese and iron ions from primary minerals are easily oxidized, which reduces mobility and bioavailability in soil (Varun et al. 2012). The mean and standard deviations show high values for $\mathrm{Al}$ equal to $1.57 \pm 0.34$ $\%$ and low values for $\mathrm{Fe}$ equal to $0.81 \pm 0.21 \%$. $\mathrm{Al}$ is one of the main constituents of soil, which commonly ranges from $0.45 \%$ to $10 \%$ (Kabata-Pendías and Mukherjee 2007). Regarding the concentration of iron in contaminated soil, it is clear that there is no contribution from a phosphogypsum deposit entering the surrounding land. The concentration of iron in the soil is naturally elevated, as evidenced by reference samples (Table 1).

In fact, some plots in the study area contain high $\mathrm{Zn}$ amountt. The minimum and the maximum of $\mathrm{Zn}$ concentrations ranged from $13.2 \mathrm{mg} \mathrm{Kg}^{-1}$ and $95.2 \mathrm{mg}$ $\mathrm{Kg}^{-1}$, respectively, with a mean value equals to 36.5 $\mathrm{mg} \mathrm{Kg}{ }^{-1}$. Moreover, in this study the highest concentration in Zinc was recorded in the site S5-1 and equaled to $282 \mathrm{mg} \mathrm{Kg}^{-1}$. This value is about 25 times higher than the reference soil and 1.5 higher than that of the phosphogypsum (Table 1), indicating a high input into the soil from the dumping grounds of phosphogypsum. As shown in Table 3, the $\mathrm{Zn}$ concentrations are not distributed homogeneously in the surface soil. Similar values have been observed by Mass et al. (2010) in contaminated soil located in the city center of Annaba in Algeria. Other studies have shown that values of areas with mining activity contaminated with $\mathrm{Zn}$ can exceed the maximal values reported in this study by over 10 times (Guo-l et al. 2008).

The distribution of $\mathrm{Pb}$ level ranges from $12.3 \mathrm{mg}$ $\mathrm{Kg}^{-1}$ to $75.2 \mathrm{mg} \mathrm{Kg}^{-1}$ with the mean value of $30.2 \mathrm{mg}$ $\mathrm{Kg}^{-1}$ (Table 3). $\mathrm{Pb}$ content arises from a variety of anthropogenic sources via exhaust fumes and industrial sources. The concentration ranges of $\mathrm{Pb}$ exceed the values recorded in the sediment underlying the coastal release of phosphogypsum sludge in Selaata (5- $35 \mathrm{mg} \mathrm{Kg}^{-1}$ ) and Akkar (6.2- $15.8 \mathrm{mg} \mathrm{Kg}^{-}$ $\left.{ }^{1}\right)$ (Abi-Ghanem et al. 2009). The impact of the phosphogypsum discharged by the Sfax chemical fertilizer company confirms an anthropogenic origin of the $\mathrm{Pb}$ enrichment.

Chromium in contaminated sites can originate from a wide variety of anthropogenic sources such as agricultural and municipal waste and atmospheric deposition from industrial sources (Kabata-Pendías and Mukherjee, 2007). In this study site, the mean value of chromium concentration is equal to $17.52 \mathrm{mg}$ $\mathrm{Kg}^{-1}$. Similar mean values have been recorded by Maas et al. (2010) in the Annaba city contaminated area and in the urban soil affected by phosphogypsum industry and traffic (Szynkowska et al. 2009). Chemical composition of phosphogypsum indicates that chromium is present in concentrations which may pose a health risk through this pathway (Rouis and Bensalah 1990). Distribution of nickel level in the studied area ranges from non-detectable to $23.2 \mathrm{mg}$ $\mathrm{Kg}^{-1}$, with the mean value of $7.23 \mathrm{mg} \mathrm{Kg}^{-1}$ and standard deviation of $5.35 \mathrm{mg} \mathrm{Kg}^{-1}$ (Table 3). The major sources of nickel contamination in the soil are metal plating industries, combustion of fossil fuels, nickel mining, and electroplating (Koudadoust et al. 2005). Low $\mathrm{Ni}$ concentrations measured in soil samples suggest that industrial activities do not lead to contamination of soil with this element.

Soil samples in the study area contain cobalt ranging from $1.38 \mathrm{mg} \mathrm{Kg}^{-1}$ to $5.28 \mathrm{mg} \mathrm{Kg}^{-1}$ with a mean value of $2.55 \mathrm{mg} \mathrm{Kg}^{-1}$ (Table 3). Cobalt usually occurs in association with other metals such as $\mathrm{Cu}$ and $\mathrm{Ni}$. One of the most important properties of Co is soil acidity. The more acidic the soil is the greater the potential of cobalt toxicity (Casas et al. 2003; Krishna and Govil 2007). As soil in the study area is neutral to 
alkaline in reaction, it is not possible to derive high values from that soil, the source, as it happens, is of anthropogenic activity from a phosphogypsum deposit. Therefore, low concentrations of Co indicate that this element does not contribute to soil contamination and can be demonstrated to be of natural origin. Relative abundance of the major elements in the studied area is shown in Table 3. The concentration of copper in the surface soil in the study site varies from 4.37 to $61.93 \mathrm{mg} \mathrm{Kg}^{-1}$, with a mean value of $15.57 \mathrm{mg} \mathrm{Kg}^{-1}$ and the median value of 10.09 $\mathrm{mg} \mathrm{Kg}{ }^{-1}$ (Table 3). This value is higher than that reported by Szynkowska et al. (2009) in the phosphogypsium contaminated aera in Poland (Wislinka), where $\mathrm{Cu}$ values range from 2.3 to 47.2 $\mathrm{mg} / \mathrm{kg}$.

\subsection{Correlation analysis}

Both Pearson (on log transformed data) and Spearman (untransformed data) correlation coefficients are statistically analyzed at the significance level of $(p<0.01)$ and $(p<0.05)$. The correlation coefficient is used to measure the degree of linear relation between logarithms of two variables and can provide suggestive information as to trace metal sources and relationships among them (AlKhashman and Shawabkeln 2006; Cai et al. 2012). It is noticed that numerous factors control their abundance, for example, original content of trace metals in soil and parent materials, various processes of soil formation, and anthropogenic factors such as contamination by human activities. Table 4 presents the Pearson correlation coefficients between soil properties and investigated elements. The findings are globally the same for the Pearson correlation. No correlation was found between the trace element content and TOC, and no significant correlation between $\mathrm{pH}$ and $\mathrm{Cu}, \mathrm{Pb}$ and $\mathrm{Zn}$. The alkalinity properties of soil in the studied area are the mean values of $\mathrm{pH}-8.17$ and can be responsible for this effect (Micó et al. 2006). Boekhold et al. (1993) have found that sorption is highly sensitive to $\mathrm{pH}$, as each increase in 0.5 of the unit in $\mathrm{pH}$ results in twice as much sorption of $\mathrm{Cd}$. These results suggest that a change in $\mathrm{pH}$ causes the transfer of elements from one phase to another; thereby permitting estimation of mobility of trace metals in the soil.

Table 4. The Person correlation for trace metal and soil properties $(N=19)$

\begin{tabular}{|c|c|c|c|c|c|c|c|c|c|c|c|c|c|c|}
\hline & pH & EC & $\begin{array}{c}\text { TO } \\
\text { C }\end{array}$ & CEC & $\begin{array}{c}\mathrm{CaCO} \\
3\end{array}$ & $\mathrm{Fe}$ & Al & Mn & $\mathbf{C u}$ & Zn & $\mathbf{P b}$ & $\mathrm{Cr}$ & $\mathbf{N i}$ & Co \\
\hline $\mathrm{pH}$ & 1 & & & & & & & & & & & & & \\
\hline $\mathrm{EC}$ & 0.19 & 1 & & & & & & & & & & & & \\
\hline TOC & -0.03 & 0.10 & 1 & & & & & & & & & & & \\
\hline $\mathrm{CEC}$ & 0.44 & 0.23 & 0.34 & 1 & & & & & & & & & & \\
\hline $\mathrm{CaCO}_{3}$ & $0.61^{* *}$ & 0.06 & 0.08 & $0.50^{*}$ & 1 & & & & & & & & & \\
\hline $\mathrm{Fe}$ & $0.77^{* *}$ & 0.20 & 0.09 & $0.77^{* *}$ & $0.62^{* *}$ & 1 & & & & & & & & \\
\hline $\mathrm{Al}$ & $0.63^{* *}$ & 0.16 & 0.24 & $0.72^{* *}$ & $0.56^{* *}$ & $\underset{* *}{0.89}$ & 1 & & & & & & & \\
\hline $\mathrm{Mn}$ & $0.72^{* *}$ & 0.11 & -0.14 & $0.61^{* *}$ & $0.48^{*}$ & $\underset{* *}{0.90}$ & $\begin{array}{c}0.78 \\
* *\end{array}$ & 1 & & & & & & \\
\hline $\mathrm{Cu}$ & 0.34 & $0.58^{* *}$ & 0.15 & 0.43 & 0.33 & 0.57 & 0.37 & 0.37 & 1 & & & & & \\
\hline $\mathrm{Zn}$ & $0.51^{*}$ & $0.41^{*}$ & 0.31 & $0.85^{* *}$ & $0.57^{* *}$ & $\underset{* *}{0.75}$ & 0.55 & 0.58 & 0.71 & 1 & & & & \\
\hline $\mathrm{Pb}$ & 0.32 & $0.50^{*}$ & 0.14 & 0.36 & 0.16 & $\underset{*}{0.48}$ & 0.29 & 0.31 & 0.91 & 0.64 & 1 & & & \\
\hline $\mathrm{Cr}$ & $0.68^{* *}$ & 0.14 & 0.32 & $0.65^{* *}$ & $0.50^{*}$ & 0.73 & 0.66 & 0.65 & 0.23 & 0.67 & 0.16 & 1 & & \\
\hline $\mathrm{Ni}$ & $0.46^{*}$ & $0.47^{*}$ & 0.29 & $0.71^{* *}$ & 0.44 & $\underset{* *}{0.69}$ & $\underset{* *}{0.76}$ & $\underset{* *}{0.60}$ & $\underset{*}{0.48}$ & $\underset{* *}{0.71}$ & 0.39 & $\underset{* *}{0.73}$ & 1 & \\
\hline $\mathrm{Co}$ & $0.49^{*}$ & 0.17 & 0.14 & $0.80^{* *}$ & $0.67^{* *}$ & 0.79 & 0.87 & 0.69 & 0.32 & 0.64 & 0.23 & 0.59 & 0.77 & 1 \\
\hline
\end{tabular}

** Correlation is significant at 0.01 levels

*Correlation is significant at 0.05 levels

Electrical conductivity shows no linear relationship with most elements except for $\mathrm{Pb}, \mathrm{Cu}$ which shows high significant correlation $(\mathrm{p}<0.01)(\mathrm{r}=$ $0.61 ; \mathrm{r}=0.57$, respectively) and moderate for $\mathrm{Zn}$ $(p<0.05) \quad(r=0.48)$. Significant positive correlations might be interpreted as an effect of the source shared by these elements. Cation exchange capacity indicates a high significant positive correlation $(\mathrm{p}<0.01)$ with all elements $\mathrm{Fe}, \mathrm{Al}, \mathrm{Cu}, \mathrm{Ni}, \mathrm{Cr}, \mathrm{Co}$ and $\mathrm{Zn}$ and a moderate positive correlation $(\mathrm{p}<0.05)$ with $\mathrm{CaCO}_{3}$, $\mathrm{pH}, \mathrm{Mn}$ and $\mathrm{Pb}$ (Table 4). On the other hand, significant positive correlation $(\mathrm{p}<0.01)$ of $\mathrm{Zn}$ with $\mathrm{Cu}(\mathrm{r}=0.79), \mathrm{Zn}$ with $\mathrm{Pb}(\mathrm{r}=0.72)$ and $\mathrm{Cu}$ with $\mathrm{Pb}(\mathrm{r}=$ $91)$ indicates that general contamination originates 
from the same source of these metals, primarily from industrial activities (Al-Khashman and Shawabkeln 2006). On the other hand, a highly positive correlation is found between $\mathrm{Al}$ and $\mathrm{Mn}(\mathrm{r}=0.73, \mathrm{P}<0.01), \mathrm{Al}$ and $\mathrm{Ni}(\mathrm{r}=0.72, \mathrm{p}<0.01), \mathrm{Al}$ and $\mathrm{Co}(\mathrm{r}=0.83, \mathrm{p}<0.01), \mathrm{Al}$ and $\mathrm{Fe}(\mathrm{r}=89, \mathrm{p}<0.01), \mathrm{Fe}$ and $\mathrm{Mn}(\mathrm{r}=0.83, \mathrm{p}<0.01)$ and $\mathrm{Fe}$ and $\mathrm{Co}(\mathrm{r}=0.78, \mathrm{p}<0.01)$, indicating that they may be of a common origin (Choura 2007). Therefore, it should be noted that high correlations of trace metals with $\mathrm{Zn}, \mathrm{Pb}$ and $\mathrm{Cu}$ and moderate correlation with major element and with $\mathrm{Al}$ and $\mathrm{Fe}$ imply that the contamination of soil is caused by lithogenic and anthropogenic activity such as industry of phosphogypsum, traffic emissions.

\subsection{Results of multivariate statistical analysis}

Principal Component Analysis (PCA), a type of multivariate analysis, is being widely used in soil and sediment pollution studies to reduce the data and to extract a smaller number of independent factors for analyzing the relationships among observed variables (Micó et al. 2006; Cai et al. 2012).The method was applied to assist or to indicate the pollution degree by trace metals from lithogenic action and anthropogenic sources. Varimax rotation with Kaiser Normalization was used in this study to perform the analysis as the rotation method, to maximize the variances of the factor loadings across the variables for each factor (Micó et al. 2006; Cai et al. 2012).

Results of the PCA for trace metal content are presented in Table 5. According to the results of the initial eigenvalues, the three principal components are considered which account for over $89 \%$ of the total variance. The eigenvalues of the two first extracted factors are greater than one and the third becomes greater than one after matrix rotation. The first component (PC1) explains $65 \%$ of the total variance. Before rotation matrix, the principal component (PC1) for nineteen samples indicates that $\mathrm{Fe}, \mathrm{Al}, \mathrm{Zn}, \mathrm{Mn}$, $\mathrm{Ni}, \mathrm{Cr}$ and $\mathrm{Co}$ are associated, and display high values greater than 0.77 , while $\mathrm{Pb}$ and $\mathrm{Cu}$ are isolated in the second factor loading. The rotated component matrix contributes to clarify these ambiguities. The elements show strong (Al, Fe, Mn and $\mathrm{Co}$ ), moderate $(\mathrm{Zn}, \mathrm{Cr}$ and $\mathrm{Ni}$ ) or weak $(\mathrm{Pb}$ and $\mathrm{Cu})$ loadings on axis One. This suggests the influence of natural sources and some anthropogenic input.

Table 5 Total variance explained and the matrix of principal components analysis after logarithmic transformation (N=19)

\begin{tabular}{|c|c|c|c|c|c|c|c|c|c|}
\hline \multirow[t]{2}{*}{$\begin{array}{l}\text { Compo- } \\
\text { nent }\end{array}$} & \multicolumn{3}{|c|}{ Initial eigenvalues } & \multicolumn{3}{|c|}{$\begin{array}{l}\text { Extraction sums of squared } \\
\text { loadings }\end{array}$} & \multicolumn{3}{|c|}{$\begin{array}{l}\text { Rotation sums of squared } \\
\text { loadings }\end{array}$} \\
\hline & Total & $\begin{array}{l}\% \text { of } \\
\text { variance }\end{array}$ & $\begin{array}{l}\text { Cumulative } \\
(\%)\end{array}$ & Total & $\begin{array}{l}\text { \% of } \\
\text { variance }\end{array}$ & \begin{tabular}{|l|} 
Cumulative \\
$(\%)$
\end{tabular} & Total & $\begin{array}{l}\% \text { of } \\
\text { variance }\end{array}$ & $\begin{array}{l}\text { Cumula- } \\
\text { tive }(\%)\end{array}$ \\
\hline \multicolumn{10}{|c|}{ Total variance explained } \\
\hline 1 & 5.859 & 65.101 & 65.101 & 5.859 & 65.101 & 65.101 & 3.406 & 37.840 & 37.840 \\
\hline 2 & 1.594 & 17.716 & 82.818 & 1.594 & 17.716 & 82.818 & 3.466 & 27.402 & 65.242 \\
\hline 3 & 0.562 & 6.243 & 89.061 & 0.562 & 6.243 & 89.061 & 2.144 & 23.819 & 89.061 \\
\hline 4 & 0.455 & 5.059 & 94.119 & & & & & & \\
\hline 5 & 0.234 & 2.597 & 96.716 & & & & & & \\
\hline 6 & 0.152 & 1.692 & 98.409 & & & & & & \\
\hline 7 & 0.087 & 0.963 & 99.371 & & & & & & \\
\hline 8 & 0.042 & 0.463 & 99.834 & & & & & & \\
\hline 9 & 0.015 & 0.166 & 100.00 & & & & & & \\
\hline & & & & & & & & & \\
\hline $\begin{array}{l}\text { Ele- } \\
\text { ment }\end{array}$ & \multicolumn{2}{|c|}{ Component matrix } & & & & \multicolumn{3}{|c|}{ Rotated component matrix } & \\
\hline \multicolumn{3}{|l|}{ PC1 } & PC2 & PC3 & & PC1 & \multicolumn{2}{|l|}{ PC2 } & PC3 \\
\hline \multicolumn{3}{|c|}{ Component matrix } & & & & & & & \\
\hline $\mathrm{Cr}$ & & 0.771 & -0.333 & 0.421 & & \multirow{9}{*}{$\begin{array}{l}0.440 \\
0.333 \\
0.828 \\
0.878 \\
0.780 \\
0.866 \\
0.480 \\
0.129 \\
0.197\end{array}$} & \multirow{9}{*}{\multicolumn{2}{|c|}{$\begin{array}{l}0.025 \\
0.607 \\
0.371 \\
0.140 \\
0.110 \\
0.188 \\
0.276 \\
0.962 \\
0.944\end{array}$}} & 0.829 \\
\hline $\mathbf{Z n}$ & & 0.856 & -0.306 & -0.229 & & & & & 0.638 \\
\hline $\mathrm{Fe}$ & & 0.949 & -0.082 & -0.210 & & & & & 0.357 \\
\hline Al & & 0.876 & -0.306 & -0.229 & & & & & 0.350 \\
\hline Co & & 0.838 & -0.311 & -0.100 & & & & & 0.436 \\
\hline Mn & & 0.830 & -0.235 & -0.315 & & & & & 0.240 \\
\hline $\mathrm{Ni}$ & & 0.856 & -0.104 & 0.295 & & & & & 0.723 \\
\hline $\mathbf{P b}$ & & 0.568 & 0.786 & -0.076 & & & & & 0.076 \\
\hline $\mathrm{Cu}$ & & 0.648 & 0.728 & -0.054 & & & & & 0.149 \\
\hline
\end{tabular}

Extraction method: principal component analysis; rotation method: Varimax with Kaiser Normalization

The component Two (PC2), which explains the $17.72 \%$ of the total variance, shows negative loading for $\mathrm{Zn}, \mathrm{Cr}, \mathrm{Co}, \mathrm{Mn}, \mathrm{Al}, \mathrm{Fe}, \mathrm{Mn}$ and high positive loading for $\mathrm{Pb}$ and $\mathrm{Cu}$. The rotation of the matrix explains a high positive loading for $\mathrm{Pb}, \mathrm{Cu}$ and $\mathrm{Zn}$ and the low loading for other elements. Low association of elements such as $\mathrm{Pb}$ and $\mathrm{Cu}$ with $\mathrm{Mn}$,
$\mathrm{Fe}$ and $\mathrm{Al}$ in soil at the studied sites indicates plainly the distinct sources for these two metals, whilst the remaining ones are associated with lithogenic inputs, but mainly with diffuse anthropogenic sources. The significant correlation coefficient between $\mathrm{Zn}, \mathrm{Cu}$ and $\mathrm{Pb}$ confirms this result and indicates that these metals are influenced by anthropogenic activities such as 
road traffic and domestic emissions. Other studies report that the strong association of elements such as $\mathrm{Co}, \mathrm{Al}, \mathrm{Mn}$ and $\mathrm{Fe}$ in soil samples suggests similar sources (Al-Khashman and Shawabklen 2006; Cai et al. 2012). The component Two represents pollution caused by industrial activities and emissions from traffic.

We conclude that the component Two represents a factor of pollution caused by industrial activities and phosphogypsum and is an important source of trace metals entering the soil for $\mathrm{Cr}, \mathrm{Zn}, \mathrm{Ni}$ and especially for $\mathrm{Pb}$ and $\mathrm{Cu}$. Regarding the correlation coefficients between $\mathrm{Al}, \mathrm{Mn}$, and $\mathrm{Fe}$, and the other heavy metals we verify that $\mathrm{Al}$ and, $\mathrm{Mn}$ and $\mathrm{Fe}$ hydroxides play a significant role in the distribution, sorption and fixation of these trace metals in soil. Similar results have been observed by Shkeri et al. (2009).

The component Three (PC3) with $6.24 \%$ of variance is high loading for $\mathrm{Cr}, \mathrm{Zn}$ and $\mathrm{Ni}$ and moderate loading for $\mathrm{Fe}, \mathrm{Al}, \mathrm{Co}$, and $\mathrm{Mn}$, and low factor loading for $\mathrm{Pb}$ and $\mathrm{Cu}$. It can be suggested that this component is affected by lithogenic and anthropogenic sources

\subsection{Results of enrichment factor analysis}

To evaluate the magnitude of trace metals in soil, the enrichment factors (EFs) have been computed for each location relative to the abundance of species in the source materials, to the control/reference value, and the equation reported by Zoller et al. (1974); Dragovic' et al. (2008) and Cai et al. (2012). They have been employed to assess the degree of contamination and to elucidate the origin of these elements. Recent suggestion shows that some elements which are naturally derived have EF near to the unity, while elements of anthropogenic origin have EF values of several orders of the magnitude (Sekabira et al. 2010), while the values greater than 1.5 mean that trace metals are derived from an anthropogenic sources such as industrial activities.

Basic statistics for EF of all analyzed elements have been determined. $\mathrm{Cu}$ has been found between depletion and minimal enrichment and significant enrichment, its minimal value is 0.56 and its maximal value is 5.47 . On the other hand, $\mathrm{Zn}$ has been depletion to minimal enrichment at its minimal value of 1.26 and moderate enrichment at its maximal value of $4.57 . \mathrm{Pb}$ is considered to have strong anthropogenic concentration, its minimal value is 1.12 and significant enrichment at a maximal value is 11.79 . $\mathrm{EF}$ of $\mathrm{Cr}$ ranges between the minimum (1.17) and the maximum (2.41) has been considered to be the depletion to the minimal and moderate enrichment, respectively. $\mathrm{Ni}$ and $\mathrm{Co}$ have a similar enrichment at minimal values which are 0 and 0.75 , respectively; their background concentration at a maximal value is moderate enrichment and equal to 1.29 and 1.68 , respectively. EFs mean values of these metals follow a descending order as: $\mathrm{Pb}>\mathrm{Zn}>\mathrm{Cr}>\mathrm{Co}>\mathrm{Cu}>\mathrm{Ni}$. The mean values are 4.81 for $\mathrm{Pb}, 2.35$ for $\mathrm{Zn}, 1.78$ for $\mathrm{Cr}, 1.68$ for $\mathrm{Co}, 1.45$ for $\mathrm{Cu}$ and 1.29 for $\mathrm{Ni}$. It is presumed and according to Harikumar and Jisha (2010) that EFs values for $\mathrm{Pb}, \mathrm{Zn}, \mathrm{Cr}, \mathrm{Co}, \mathrm{Cu}$, and $\mathrm{Ni}$ are higher than 1.5 indicating that the phosphate fertilizer industry causes a strong anthropogenic impact and leads to the accumulation of these trace metals in surrounding soils.

\section{Conclusion}

This study has revealed the existence of a medium to high polluted zone surrounding the environment of the phosphate fertilizer industry in the vicinity of Sfax. Statistical analyses including principal component analysis (PCA) and correlation coefficients are used to estimate the degree of linear relation between logarithms of two variables and can provide suggestive information regarding trace metal sources and relationships among trace metals and other properties. Results show significant positive correlation between the majorities of detected trace metals. In the cases of $\mathrm{Cu}, \mathrm{Zn}$ and $\mathrm{Pb}$ the enrichment factor values are found to be greater than 1.5. In general, these results confirm the source of contamination to be anthropogenic industrial activities in the region of Sfax, which have led to contamination of soil in this area. The mean of trace metals follows a descending order as $\mathrm{Zn}>\mathrm{Pb}>\mathrm{Cr}>\mathrm{Cu}>\mathrm{Ni}>\mathrm{Co}$. Two main sources of these studied elements, as well as some subdivided sources, are identified. $\mathrm{Ni}$ and $\mathrm{Co}$ originate from soil materials, but $\mathrm{Zn}, \mathrm{Pb}, \mathrm{Cr}$ and $\mathrm{Cu}$ are anthropogenic inputs. This study presents an original survey distribution pattern of heavy metals in the soil surrounding the phosphogypsum dump, as well as the progressive enrichment in $\mathrm{Zn}, \mathrm{Cu}$ and $\mathrm{Pb}$ concentrations in soil due to PG. Mobility and bioavailability of heavy metals in soil or sediments and their potential toxicity need to be studied further.

\section{Acknowledgments}

The research has been financially supported by the University of Sfax and the Minister of Research of Tunisia. The Laboratory of Soil Science in Gembloux, Belgium has come to technical assistance. The authors also thank all members and technicians of the Laboratory of Soil Science for their help in technical work.

\section{References}

Abi-Ghanem, C., Chiffoleau, J.F., Bermond, A., Nakhlé, K., Khalaf, G., Borschneck, D and Cossa, D. Lead and its isotopes in the sediment of three sites on the Lebanese coast: Identification of contamination sources and mobility. Applied Geochemistry, 2009, 24 (10), p. 9901999. http://dx.doi.org/10.1016/j.apgeochem.2009.07.012

Al-Khashman, O.A and Shawabkeln, R.A. Metals distribution in soils around the cement factory in southern 
Jordan. Environnemental Pollution, 2006, 140, p. 387-394. http://dx.doi.org/10.1016/j.envpol.2005.08.023

Al-Masri, M.S., Amin, Y., Ibrahim, S and Al-Bich, F. Distribution of some traces metals in Syrian phosphogypsum. Applied Geochemistry, 2004, 19, p. 747753. http://dx.doi.org/10.1016/j.apgeochem.2003.09.014

Azabou, S., Mechichi, T and Sayadi, S. Sulfate reduction from phosphogypsum using a mixed culture of sulfate-reducing bacteria. International Biodeterioration and Biodegradation, 2005, 56, p. 236-242. http://dx.doi.org/10.1016/j.ibiod.2005.09.003

Boekhold, A.E., Temminghoff, E.J.M and Van der Zee, S.E.A.T.M. Influence of electrolyte composition and $\mathrm{pH}$ on cadmium sorption by an acid sandy soil. European Journal of Soil Science, 1993, 44 (1), p. 85-96. http://dx.doi.org/10.1111/j.1365-2389.1993.tb00436.x

Cai, L., Xu, Z., Ren, M., Guo, Q., Hua, X., Hua, G., Wan, $\mathrm{H}$ and Peng, P. Source identification of eight hazardous heavy metals in agricultural soils of Huizhou, Guangdong Province, China. Ecotoxicology and Environmental Safety, 2012, 78, p. 2-8. http://dx.doi.org/10.1016/j.ecoenv.2011.07.004

Carvalho F. $210 \mathrm{~Pb}$ and $210 \mathrm{Po}$ in sediments and suspended matter in the Tagus estuary, Portugal. Local enhancement of natural levels by wastes from phosphate ore processing industry. Science of the Total Environment, 1995,159 , p. 201-214

Casas, J.M., Rosas, H., Sole, M and Lao, C. Heavy metals and metalloids in sediments from the Liobreget basin, Spain. Environmental Geology, 2003, 44, p. 325-332. http://dx.doi.org/10.1007/s00254-003-0765-6

Chakchouk, M and Trabelsi, F. 1989. Contribution à l'etude de la recuperation des eaux de rejet de l'use SIAPE "A". Research report, Ecole Nationale d'ingenieurs de Sfax, Tunisia.

Choura, M. 2007. Short and medium action program III-Tunisia: Environmental evaluation of the treatment of phosphate in the south coastal zone of Sfax. Municipally of Sfax, Internal report, Tunisia.

Ciavatta, C., VittoriAntisari, L and Sequi, P. Determination of organic carbon in soils and fertilizers.Commun. Soil Science and Plant Analysis, 1989, 20, p. 759-773.

http://dx.doi.org/10.1080/00103628909368115

Covelo, E.F., Vega, F.A and Andrade, M.L Simultaneous sorption and desorption of $\mathrm{Cd}, \mathrm{Cr}, \mathrm{Cu}, \mathrm{Ni}, \mathrm{Pb}$ and $\mathrm{Zn}$ in acid soils II: soil ranking and influence of soil characteristics. Journal of Hazardous Materials, 2007, 147, p. 862-870. http://dx.doi.org/10.1016/j.jhazmat.2007.01.108

Deka, J and Sarma, H.P. Heavy metal contamination in soil in an industrial zone and its relation with some soil properties. Archives of Environmental Contamination and Toxicology, 2012, 4 (2), p. 831-836.

Dragovic', S., Mihailovic,' N., and Gajic', B. Heavy metals in soils: Distribution, relationship with soil characteristics and radionuclides and multivariate assessment of contamination sources. Chemosphere, 2008, 72, p. 491-495.

http://dx.doi.org/10.1016/j.chemosphere.2008.02.063

Ergin, M., Saydam, C., Ba stürk, Ö., Erdem, E and Yörük, R. Heavy metal concentrations in surface sediments from the two coastal inlets (Golden Horn Estuary and Izmir Bay) of the northeastern sea of Marmara. Chemical Geology, 1991, 91, 269-285. http://dx.doi.org/10.1016/0009-2541(91)90004-B

Gargouri, D., Azri, C., Serbaji, M.M., Jedoui, Y. and Montacer, M. Heavy metal concentrations in the surface marine sediments of Sfax Coast, Tunisia. Environmental Monitoring and Assessment, 2010, DOI10.1007/ s10661010-1548-7.

Ghannem, N., Azri, C., Serbaji, M. M. and Yaich, C. Spatial distribution of heavy metals in the coastal zone of "Sfax-Kerkennah" plateau, Tunisia. Environmental Progress and Sustainable Energy, 2010, 30 (2), doi: 10, $1002 / \mathrm{ep}$

Guo-1, L., Da-xue, L.I.A.O and Quan-ming, L. Heavy metals contamination characteristics in soil of different mining activity zones. Transactions Nonferrous Metals Society of China, 2008, 18, p. 207-211. http://dx.doi.org/10.1016/S1003-6326(08)60037-0

Harikumar, P.S and Jisha, T.S. Distribution parttern of trace metal pollutants in the sediments of an urban wetland in the southwest coat of India. International Journal of Engineering Science and Technology, 2010, 2 (5), p. 840850 .

ISO 23470. 2007. Soil quality- Determination of effective cation exchange capacity (CEC) and exchangeable cations using a hexamminecobalttrichloride solution.

Kabata-Pendías, A and Mukherjee, A.B. 2007. Trace elements from soil to human. Berlin: Springer.

Kobbi-Rebai, R., Annabi-Trabelsi, N., Khemakhem, H., Ayadi, H., Aleya, L. Impacts of restoration of an uncontrolled phosphogypsum dumpsite on the seasonal distribution of abiotic variables, phytoplankton, copepods, and ciliates in a mean-made solar saltern. Environmental, Monitoring and Assessment, 2012, DOI 10, 1007/S10661012-2695-9.

Khodadoust, A.P., Reddy, K.R and Maturi, K. Effect of different extraction agents on metal and organic contaminant removal froma field soil. Journal of Hazardous Materials, 2005, 117(1), p. 15-24. http://dx.doi.org/10.1016/j.jhazmat.2004.05.021

Krishna, A.K and Govil P. K. Soil contamination due to heavy metals from an industrial area of Surat, Gujarat,Western India. Environmental Monitoring and Assessment, 2007, 124, p. 263-275. http://dx.doi.org/10.1007/s10661-006-9224-7

Lee, C.S.L., Li, X.D, Shi, W., Cheung SC-N and Thornton, I. Metal contamination in urban, suburban and country park soils of Hong Kong: a study based on GIS and multivariate statistics. Science of the Total Environment, 2006, 356, p. 45-61.

http://dx.doi.org/10.1016/j.scitotenv.2005.03.024 
Lee C.S.L., Li, X.D, Zhang, G., Li, J., Ding, A.J and Wang, $\mathrm{T}$. Heavy metals and $\mathrm{Pb}$ isotopic composition of aerosols in urban and suburban areas of Hong Kong and Guangzhou, South China-evidence of the long-range transport of air contaminants. Atmospheric Environment, 2007, 41(2), p. 432-447.

http://dx.doi.org/10.1016/j.atmosenv.2006.07.035

Lucho-Constantinoa, C.A., A' lvarez-Sua'rezb,M., Beltra'n-Herna'ndez,R.I., Prieto-Garci', $F$ and PoggiVaraldoa, H.M. A multivariate analysis of the accumulation and fractionation of major and trace elements in agricultural soils in Hidalgo State. Mexico irrigated with raw wastewater. Environment International, 2005, 31, p. 313323. http://dx.doi.org/10.1016/j.envint.2004.08.002

Maas, S., Scheifler, R., Benslama, M., Crini, N., Lucot, E., Brahmia, Z., Benyacoub, S and Giraudoux, P. Spatial distribution of heavy metal concentrations in urban, suburban and agricultural soils in a Mediterranean city of Algeria. Environmental Pollution, 2010, 158, p. 2294-2301. http://dx.doi.org/10.1016/j.envpol.2010.02.001

Micó, C., Recatala, L., Peris, M and Sanchez J. Assessing heavy metal sources in agricultural soils of a European Mediterranean area by multivariate analysis. Chemosphere, 2006, 65, p. 863-872.

http://dx.doi.org/10.1016/j.chemosphere.2006.03.016

NFX 31-147. 1996. Soil quality- Soils, sedimentsTotal solubilising by acid attack.

Perez-Lopez, R., Nieto, J.M., Lopez-Coto, I., Aguado, J.L, Bolivar, J.P., Santisteban, M. Dynamics of contaminants in phosphogypsum of the fertilizer industry of Huelva (SW Spain): From phosphate rock ore to the environment. Applied Geochemistry, 2010, 25, 705-715. http://dx.doi.org/10.1016/j.apgeochem.2010.02.003

Rayment, G.E and Higginson F. R. 2002. Australian handbook of soil and water chemical methods. Inkata. Presse Melbourne.

Rouis, M.J and Bensalah, A 1990. Phosphogypsum in Tunisia: environmental problems and required solutions. Volume I, p. 87-105. In Proceedings of the Third International Symposium on phosphogypsum, Orlando. Sfax, Tunisia publication.

Rutherford, P.M., Dudas, M.J and Smak, R.A. Environmental impacts of phosphogypsum. Science of the Total Environment, 1994, 149, p. 1-38. http://dx.doi.org/10.1016/0048-9697(94)90002-7

Sekabira, K., OryemOriga, H., Basamba, T.A., Mutumba, G and Kakudidi E. Assessment of heavy metal pollution in the urban stream sediments and its tributaries. International journal environmental science and technology, 2010, 7(4), 435-446. http://dx.doi.org/10.1007/BF03326153

Shakeri, A., Moore, F and Modabberi, S. Heavy Metal Contamination and Distribution in the Shiraz Industrial Complex Zone Soil. South Shiraz, Iran. World Applied Science Journal, 2009, 6 (3) (2), p. 413-425.

Sun, L., Chen, S., Chao, L and Sun, T. Effects of flooding on changes in $\mathrm{Eh}, \mathrm{pH}$ and speciation of cadmium and lead in contaminated soil. Bulletin of Environmental Contamination and Toxicology, 2007, 79, p. 514-518. http://dx.doi.org/10.1007/s00128-007-9274-8
Szynkowska, M. I., Pawlaczyk, A., Leśniewska, E., Paryjczak, T. Toxic Metal Distribution in Rural and Urban Soil Samples Affected by Industry and Traffic. Polish Journal of Environmental Studies, 2009, 18(6) p, 11411150 .

Tayibi, H., Choura, M., Lo' pez, F.A., Alguacil, F.J and Pez-Delgado, A.L. Environmental impact and management of phosphogypsum. Journal of Environmental Management, 2009, 90, p. 2377-2386. http://dx.doi.org/10.1016/j.jenvman.2009.03.007

United States Salinity Laboratory Staff. 1954. Diagnosis and improvement of saline and alkali. U.S Deputation Agricultures Handbook no. 60.59, p. 57-63.

Varun, M., D'Souza, R., Pratas, J and Paul, M.S. Metal contamination of soils and plants associated with the glass industry in North Central India: prospects of phytoremediation. Environmental Science and Pollution Research, 2012, 19, p. 269-281. http://dx.doi.org/10.1007/s11356-011-0530-4

Vega, F.A., Covelo, E.F., Andrade, M.L and Marcet, P. Relationship between heavy metals content and soil properties in mine soils. Analytica Chimica Acta, 2004, 524, p. 141-150. http://dx.doi.org/10.1016/j.aca.2004.06.073

Zoller, W.H., Gladney, E.S and Duce, R.A. Atmosphere concentrations and sources of trace metals at the South Pole. Science, 1974, 183, p. 199-201. http://dx.doi.org/10.1126/science.183.4121.198

PhD student Ahmed Wali - Laboratory of Water, Energy and Environment, University of Sfax, Tunisia.

Main research area: Environmental Chemistry

Address: ENIS B.P 1173-3038 road of Soukra km 3.5 Sfax Tunisia

Tel.: $\quad+21620934473$

E-mail: waliahmed@ymail.com

Researcher Gilles Colinet - of the Unit of Soil and Water Systems, University of Liege, Gembloux Agro-Bio Tech, Belgium.

Main research area: Soil Science

Address: Passage of Deportees

Tel.: $\quad 081 / 62.25 .39$

E-mail: Gilles.Colinet@ulg.ac.be

Researcher Moncef Khadhraoui -of the Laboratory of Water, Energy and Environment, University of Sfax, Tunisia.

Main research area: Environmental Chemistry

Address: ENIS B.P 1173-3038 road of Soukra km 3.5 Sfax Tunisia

Tel.: $\quad+21697233461$

E-mail: montunisia@yahoo.fr

Researcher Ksibi Mohamed -of the Laboratory of Water, Energy and Environment, University of Sfax, Tunisia. Main research area: Environmental Biotechnology

Address: ISBS B.P 1175, 3038 road of Soukra km 3.5 Sfax

Tunisia

Tel: $\quad+216674354$

Email: mohamed.ksibi@tunet.tn 


\title{
Fosfatų pramonės dirvožemio tarša pėdsakiniais metalais Sfakse- Tuniso teritorijoje
}

\author{
Ahmed Wali ${ }^{1}$, Gilles Colinet ${ }^{1}$, Moncef Khadhraoui ${ }^{2}$, Mohamed Ksibi ${ }^{1}$ \\ ${ }^{1}$ Energetikos ir aplinkotyros universitetas, Vandens laboratorija, Tunisas \\ ${ }^{2}$ Lježo universitetas, Dirvožemio ir vandens sistemos, Belgija
}

(gauta 2013 m. birželio mèn., priimta spaudai 2013 m. rugsèjo mèn.)

Visame pasaulyje vis labiau rūpinamasi dirvožemio tarša, kuri yra sąlygojama fosfatụ pramonëje susidariusiu didelio fosfogipso srutų kiekio. Šios srutos yra pumpuojamos iš pramonès gamybos įrenginių ị rūgščius nuotekų tvenkinius, kurie yra šalia didžiulių sukrautų gipso atliekų kiekių, vadinamujų gipso atliekų kalnų. Taip pavojingi metalai, esantys srutų atliekose, gali prasiskverbti i aplinką, gruntinius vandenis ir sukelti pavojų gyviesiems organizmams.

Šio tyrimo tikslas - ištirti dirvožemio, esančio šalia fosfatų trąšu pramonès įmonès, mikroelementų sudètį, koncentracijas ir nustatyti veiksnius, lemiančius jų kiekių pasiskirstymą. Dirvožemio mèginiai buvo imami $20 \mathrm{~cm}$ gylyje, nustatomos fizikinès ir cheminès savybès, atliekama mikroelementų $(\mathrm{Ca}, \mathrm{Mg}, \mathrm{K}, \mathrm{Na}, \mathrm{Al}, \mathrm{Fe}, \mathrm{Mn})$ ir sunkiujų metalų $(\mathrm{Zn}, \mathrm{Pb}, \mathrm{Cr}, \mathrm{Cu}, \mathrm{Co}$ ir Ni) analizè. Ryšiams tarp sunkiụjų metalų kiekių ir veiksnių, sąlygojančių jų sklaidą dirvožemyje, rasti duomenys buvo analizuojami taikant daugiafaktorinès statistinès analizès metodą. Praturtinimo faktorius (Enrichment factor $(E F)$ ) buvo skaičiuojamas tam, kad būtų nustatyta sunkiưjų metalų kilmè: natūrali ar antropogeninè. Eksperimento rezultatai atskleidè vidutinị dirvožemio užterštumą ir netolygų cheminių elementų kiekių pasiskirstymą. Maksimalios ir vidutinès pèdsakiniu metalu koncentracijos buvo nustatytos daugelyje (išskyrus S5.1) mėginių: Zn (95.2 ir $\left.36.5 \mathrm{mg} \mathrm{Kg}^{-1}\right)$; $\mathrm{Pb}\left(75.2\right.$ ir30.23 mg Kg$\left.{ }^{-1}\right)$; $\mathrm{Cr}\left(28.4\right.$ ir $\left.17.5 \mathrm{mg} \mathrm{Kg}^{-1}\right)$; $\mathrm{Cu}(61.9$ ir $15.6 \mathrm{mg}$ $\mathrm{Kg}^{-1}$ ); Co (5.28 ir $2.7 \mathrm{mg} \mathrm{Kg}^{-1}$ ) ir Ni (13.2 ir $6.4 \mathrm{mg} \mathrm{Kg}^{-1}$ ). Dauguma metalu koncentracijų kiekiai teigiamai koreliavo su $\mathrm{pH}$ ir katijonų talpos reikšmèmis. Koreliacijos nebuvo nustatyta su bendrosios organinės anglies kiekiu ir elektros laidumu, išskyrus tokius elementus: $\mathrm{Cu}, \mathrm{Zn}$ ir $\mathrm{Pb}$. Praturtinimo faktoriaus reikšmės buvo gautos didesnès negu 1,5. Tai rodo antropogeninį neigiamą poveikị dirvožemiui, sąlygotą fosfatų trąšŭ pramonès ịmonès. Dèl sąlyginai padidèjusios pavojingos taršos tirtame dirvožemyje turi būti sugriežtintos žemės naudojimo sąlygos žemės ūkio ir gyventojų tikslams. 